\title{
Economic Effects of the Recently Signed Pak-China Free Trade Agreement
}

\author{
Samina Shabir* and Reema Kazmi**
}

\section{Abstract}

Factor endowments and cross country differences create regional disparities among states. The disparity in sizes between the Chinese and Pakistani economies can lead to the creation of trade patterns that can positively or negatively impact the latter's economy. The present paper attempts to analyze the pros and cons of forming a Free Trade Agreement (FTA) with China given the size, structure and trade patterns of Pakistan's existing economy. It also deals with the crucial questions of: Can the formation of an FTA with China benefit Pakistan? Will trade liberalization under an FTA with a neighboring country like China spur Pakistan's trade and growth? Looking at trends and trade patterns of Pakistan, the potential of Pakistan's existing economy is analyzed to enhance interregional trade and export diversification by further deepening cooperation with China. In the light of this analysis, the paper also outlines a number of recommendations to extract the maximum benefit for Pakistan's economy from this recently signed FTA with an old economic partner, China.

\section{Introduction}

Free trade or globalization is a hotly debated phenomenon in the global village of today's economic system. If the economic prosperity and growth of all the nations of the world could be brought at par with each other by the free flow of goods and services, regardless of borders, under the free trade banner, then it is a scenario for which every one of us should strive for. However, according to skeptics, this concept of Free Trade is nothing but a mirage. The observed reality is that the World Trade Organization (WTO) which is the international flag bearer of free trade has so far not been successful in bringing about trade liberalization around the globe. There is a perception that the WTO seems to be biased toward

\footnotetext{
* Debt Office, Ministry of Finance Government of Pakistan, Islamabad.

${ }^{* *}$ Debt Office, Ministry of Finance, Government of Pakistan, Islamabad.
} 
industrialized and already developed countries, safeguarding and advancing their interests, thus further worsening the lot of the world's poor. This failure or loss of credibility of the WTO has led developing countries to fend for their own interests in this increasingly integrated but regionalized world. Bilateral trading arrangements, although less preferred to multilateral ones, are one of the instruments employed by various countries, both developed and developing, to secure their export markets and to guarantee their trading activities in the future.

Free Trade Agreements (FTAs) are a common type of bilateral arrangement between two or more countries. FTAs facilitate the free flow of trade and investment and bring about closer economic integration between the binding parties by eliminating tariff/restrictions on each other's commodities. More than $60 \%$ of global trade, at the moment, is being channeled through bilateral and regional trading arrangements. At present, almost 300 such arrangements exist globally. The purpose of these FTAs is not only to serve the economic needs of two countries, but to also accommodate political motivations, or in other words, legitimatize trade between two coalition allies (the recent US - Panama FTA is an example). A host of industrialized countries have already established bilateral arrangements (e.g., EU, NAFTA etc.), mostly among themselves. With the realization of the growing importance of FTAs, some developing countries have also entered into these arrangements. The recently signed Pakistan China FTA is a move in the same direction. With the growing importance of emerging economies in South and East Asia, Asia Pacific and South America, Pakistan is aiming at strengthening its trading relations with the economies of those regions. With the growing importance attached to China as the fourth largest economy of the world as well as an immediate neighbor of Pakistan, it is about time for Pakistan to think about strengthening its economic ties, apart from their already strong strategic and military relations. It was with this enthusiasm and aim in mind that Pakistan laid the foundation for an FTA arrangement with China in July, 2006.

China being the fourth largest economy of the world, with a trade surplus of $\$ 30$ billion and foreign exchange reserve of $\$ 1$ trillion, has strategically moved from being a centrally planned to a market based economy. At the end of 2006, China's global trade exceeded \$1.758 trillion. Pakistan in comparison, is an emerging economy with nominal GDP of $\$ 128.5$ billion, a trade deficit of $\$ 8.51$ and foreign exchange reserves in excess of $\$ 13$ billion. Given the disparity in the sizes and economies of these two countries, entering into an FTA arrangement at this point in time can lead to some very crucial implications for both the countries, especially for Pakistan. Thus, this paper attempts to explore the implications of the FTA 
between China and Pakistan on Pakistan's economy. A case in point is the textile sector of Pakistan which is an important contributor to the country's overall exports, while China is also very competitive in this sector - leading to a clash in interests. Therefore, it is imperative to analyze the implications of the FTA for various sectors of Pakistan's economy. Likewise, a huge historic trade deficit with China makes it necessary to see the impact of this FTA on trade with China and Pakistan in general. A number of Chinese firms were operating in Pakistan, even before the establishment of the FTA, so now this also requires us to explore the investment scenario in Pakistan. This study analyzes all these impacts in detail.

The objective of the present paper is to examine the impact of the recently signed Pak-China Free Trade Agreement (FTA) on Pakistan's economy. The paper has been structured as follows: Section II deals with Pakistan-China trade and economic ties; Section III looks at the already signed FTA of Pakistan and China with various other countries; Section IV analyzes the economic impact of FTA on Pakistan's economy in detail and Section V presents the conclusions of the paper.

\section{Pakistan China Trade and Economic Relations}

The year 2006 marks the completion of 55 years of cordial relations between Pakistan and China. Over all these years, the two countries have been able to evolve a cooperative relationship at multiple levels, especially in the political, defense and diplomatic arenas. However, Pakistan and China have not been able to make substantial progress in their economic relations until recently.

At the dawn of the 21st century and with the implementation of the WTO regime just around the corner, both the countries realized the missing economic dimension in their evolving strategic relationship. The two countries thus acknowledged the fact that in order to sustain a comprehensive cooperative relationship, substantive economic collaboration, in line with the level of political and strategic coordination, was imperative. Economic cooperation would not only consolidate the comprehensive bilateral relations between the two countries, but also help in achieving common aspirations for development, peace and stability in the region. In the last few years or so, the two governments have convened a number of high-level conferences/forums, inaugurated by their respective leadership in Pakistan and China, to promote economic cooperation thereby exhibiting interest, resolve and patronage to the private sector business community of the two countries. Pakistan and China have now successfully created a clear and shared vision of the direction of their economic relations. However, the 
results of this evolving economic cooperation would only be realized after the upcoming implementation of the agreements reached at various levels on trade and investment.

Since the early 1950s, Pakistan and China have entered into trade relations; however, the first formal Trade Agreement was signed in January 1963. Later, in October 1982, the two countries established the PakistanChina Joint Committee on the Economy, Trade and Technology. Trade between China and Pakistan had generally been conducted under the 1963 Trade Agreement, according to which both countries had granted MFN status to each other. Pakistan had, at that time, multi-modal trade with China i.e. barter trade and cash trade. However, at present trade with China is conducted almost entirely on a cash basis in convertible currency. Recently, the economic relationship between China and Pakistan has come to the forefront. Now the question arises as to why this sudden interest in trade between the two countries has suddenly been ignited. Amongst other reasons, one is that the Chinese government has persuaded its statecontrolled enterprises to import Pakistani products in order to improve the trade balance and make more project-specific investments. The private sector's engagement, which would be the main engine for growth in bilateral economic relations in the future, is still at a low level. On the other hand, compliance with the WTO regime is imminent and thus countries are on the look out for the consolidation of ties with their most dependable trading partner. In the case of Pakistan, that dependable trading partner as well as a neighbor is China. Thirdly, logistically an all-reaching trading agreement with a neighborly state like China is economically rational and cost effective. Thus, with the rest of the world already well on its way towards economic integration with like minded allies, Pakistan has also started to follow this well treaded path.

Traditionally, throughout its trade relations with China, Pakistan has had a chronic trade deficit. This is primarily because China is competing in almost all the major sectors of Pakistan's potential export areas, which happen to be very limited. Secondly, the Pakistani business community remained content with their established export destinations i.e., the US and the Western Europe, and hardly made serious efforts to either diversify the export base or to explore other areas and regions for enhancing the volume of their exports. This fixation with Western markets and non-innovative export approach has consistently undermined the country's export potential. Third, though it was feared initially that cheap Chinese products could take over the Pakistani market, this trend abated once people realized that they were of low quality, with almost no guarantee by the company. This was true for both small items, such as 
shoes, as well as bigger items, such as locomotives. Fourth, Chinese brands were not as famous as the western ones, so competition usually went against China. Fifth, despite being neighbors, there was a lack of effective means of communication between Pakistan and China. The Karakorum Highway, which opened in 1978, could not be used to increase the volume of trade in any substantial manner. In addition, an underdeveloped shipping industry in Pakistan further limited the trade routes and discouraged the growth in trade volume. Sixth, Pakistan's cotton based industry is the main pillar of its exports. Since China itself is a major textile manufacturer, the trade volume could not be raised.

As a result of this renewed interest in trade relations, on May 12 2001, Pakistan and China signed six agreements and one Memorandum of Understanding (MoU). At that time, Chinese financial assistance for the agreed projects was estimated to be worth over one billion dollars. This signing of agreements can be termed as the first round of a substantive initiative for expanding economic cooperation. The agreements signed included: Economic and Technical Cooperation, Tourism Cooperation, Lease Agreement on Saindak Copper-Gold Project, Supply of Locomotives to Pakistan Railways, Supply of Passenger Coaches to Pakistan Railways, White Oil Pipeline and MoU between China's ZTE and Pakistan Telecommunications Co. Ltd. Under the Agreement on Economic and Technical Cooperation, the Chinese government agreed to provide a grant of 50 million Yuan for the promotion of economic and technical cooperation between the two countries.

China, meanwhile, also reiterated support for a project which is very close to the Pakistani people's hearts. Thus, almost a year later, on March 22, 2002, General Musharraf and the Chinese Vice Premier, Wu Bang Guo, attended the ground-breaking ceremony of the Gwader sea-port. Phase one of Gwader port was successfully completed in April 2005, and work on the second phase is in progress.

In the following years, there has been a regular exchange of highlevel visits between the two countries and each visit added new dimensions and areas for economic cooperation. For example, President Musharrafs visit in November 2003 resulted in the signing of a Joint Declaration on Direction of Bilateral Relations. It was in fact a road-map determining the direction and scope of overall Pak-China bilateral relations in the future.

In December 2004, Pakistan and China again signed seven agreements in trade, communication and the energy sector and drew up a framework for greater cooperation. These agreements envisaged an increase 
in bilateral trade, further movement on the preferential trade agreement, the setting up of joint agro-based industries and increased Chinese investment in Pakistan. Pakistan announced Free Market Economy (FME) status for China. Also, China committed to provide $\$ 150$ million for the Chashma Nuclear Power Plant (Phase II). It was part of the preferential buyers' credit of $\$ 500$ million to be provided by the Chinese government for investment through Chinese companies. China's investment in Pakistan at present stands at US $\$ 4$ billion plus, and at least 114 Chinese projects are underway. The Chinese side also agreed that the Joint Economic Commission should soon review Pakistan's proposal to set up a PakistanChina Joint Investment Company and the establishment of a Joint Infrastructure Development Fund for investment in Pakistan.

The Chinese Prime Minister's April 2005 visit was considered a landmark visit in which the two sides signed 21 agreements and MoUs on cooperation in economic matters, defense, energy, infrastructure, the social sector, health, education, higher education, housing and other areas. The two sides also signed a Treaty of Friendship, Cooperation and Good Neighborly Relations. Under the agreement on Early Harvest Program (EHP), which became operational on January 1, 2006, China has reduced tariffs to zero on 767 items. This was the first step towards establishing a free trade area between the two countries. It is envisaged that by the year 2008, Pakistan and China would be fully able to implement the FTA, covering $90 \%$ of the commodities. The remaining $10 \%$ would remain on the sensitive list of commodities and tariffs might be removed, or at least toned down, during the second round of FTA negotiations scheduled to be held in 2011 and be implemented in 2012. During the recent visit of the Chinese President to Pakistan in November 2006, the two countries signed 18 agreements, including a free trade pact/agreement, which they hope will boost trade from $\$ 4.26$ billion last year to $\$ 15$ billion within the next five years. The two sides have also signed a pact on a five-year plan to set up a comprehensive framework for boosting economic ties. Pakistan provides the shortest possible route, from Gwader through the Karakorum Highway, to the Western regions of China, which are undergoing a huge economic transformation. This route is secure, short and can serve as an alternative to the sea route that passes through the Straits of Malacca. Both countries have been focusing on trade interaction through this route. 
As a result of the concerted efforts and determination to enhance economic cooperation between both sides, trade between the two countries has been registering constant growth: from $\$ 1.07$ billion in 1997 , to $\$ 3$ billion in 2004 , to $\$ 4.26$ billion in 2005 , and the estimated trade volume in 2006 is at $\$ 5$ billion. Therefore, in a short span of eight years, the trade volume between China and Pakistan has increased by around $\$ 3.2$ billion not a paltry amount by any standards. Although the current trade balance is still heavily in favor of China, the opportunities for Pakistani exports to China are growing. According to the Chinese Customs Authority, "Pakistan's export to China showed an upward trend, registering an increase of about $39.2 \%$ in 2005 . The exports amounted to $\$ 832$ million from January to December 2005 , whereas it was at $\$ 594$ million in the same period during the previous year (January-December 2004). Therefore, the increase in Pakistan's exports to China in a period of one year has amounted to about $\$$ 238 million." It is expected that if Pakistan's economy continues to achieve its current growth rate, bilateral trade would touch around US\$ 8 billion by 2008.

During the President of Pakistan's recent visit, the two sides inked 13 agreements and one $\mathrm{MoU}$, aimed at boosting bilateral economic cooperation while covering a wide range of issues, including trade and economic cooperation as well as cooperation on energy, transportation, agriculture, health, population, seismology and meteorology. A feasibility study is also being conducted to make Pakistan China's "trade and energy corridor." Thereby, upgradation of economic cooperation has become an integral part of the overall Pakistan-China strategic cooperation. The institutionalization of economic relations through the above-mentioned visits have laid the foundation and set the direction of the cooperative relationship of Pakistan-China.

Although the two-way trade has increased, the volume of trade is still low. Traditionally, the trade balance has always been titled in favor of China, except for a short while in 1952, owing to China's involvement in the Korean War. For decades China's constant increase in exports to Pakistan resulted in a persistent and growing trade imbalance. The main items of Pakistan's imports from China are machinery and parts, iron and steel manufactures, sugar, chemical materials, chemical elements and medical and pharmaceutical products. The main items of Pakistan's exports to China are cotton fabrics, cotton yarn, petroleum and its products, fish and its preparations, leather, fruits and vegetables. Unfortunately, the mix of Pakistan's products exported to China is very narrow. Almost around $80 \%$ of its exports consist of cotton yarn and fabric. 
Pakistan's exports to China lack diversity and both countries are competitors in the textile sector. Diversification of exports from Pakistan into non-traditional items will help minimize the trade imbalance. Another important factor in trade deficit with China is the growing exports of Chinese products to Pakistan. Since these are more economical, businessmen are inclined to buy more from China. Pakistan therefore, should be looking at China not simply as an export market but as a primary source for the import of capital goods and industrial raw material.

The two countries signed a Preferential Trade Arrangement (PTA) in November 2003, which has been operational since January 1, 2004. Pakistan and China instituted a Joint Study Group to negotiate a Free Trade Agreement between the two countries and have simultaneously negotiated an Early Harvest Programme (EHP), which became operational on January 1, 2006.

According to Pakistan's Ministry of Commerce, Pakistan has given market access on 118 tariff lines of organic chemicals and 268 tariff lines of machinery - 386 tariff lines in total. Except 30 tariff lines, 13 relating to organic chemicals and 17 relating to machinery, all the other tariff lines have an MFN rate of $5 \%$. As per the agreed timeframe of the elimination of tariffs, Pakistan was required to reduce the tariff only on 30 tariff lines by January 1, 2006. The tariff on the rest of the tariff lines i.e. 356 tariff lines was reduced to zero on January 1, 2007 i.e. no immediate revenue implications. Similarly, China has brought to zero all tariffs on 767 items.

\section{Pakistan-China Investment Relations}

Pakistan and China on February 12, 1989 signed a Bilateral Investment Treaty (BIT) that encourages the promotion of bilateral investment both in China and Pakistan, and covers all kinds of investments, protects investors and investments of both the countries against discrimination and expropriation, seeks fair and equitable treatment and provides a dispute resolution mechanism.

The overall Foreign Direct Investment (FDI) in Pakistan has risen by over $600 \%$ in the last five years. However, the Chinese share in the overall FDI is still very low. Pakistan has been able to introduce and implement investor friendly policies as a result of which FDI has increased. Pakistan's investment policy is very liberal which makes available all economic sectors for FDI. It provides equal treatment to local and foreign investors and allows $100 \%$ equity to foreign investors with no government sanction required. Full remittance of profits, capital, dividends, royalties, technical and franchise fees is allowed. 
Complete legal cover is provided through Foreign Private Investment (Promotion \& Protection) Act 1976, Protection of Economic Reforms Act 1992, and Foreign Currency Accounts (Protection) Ordinance 2001.

Similarly, the Chinese government encourages foreign investment in the Chinese market, and has continuously liberalized and expanded the fields for investment. In recent years, China has further liberalized the restrictions imposed on the proportion of foreign equity in investment projects and opened new sectors to foreign investment. The newly-opened sectors include telecommunications, urban water supply and drainage, construction and the operation of gas and heat distribution networks, which were all previously prohibited from any foreign investment. China has also opened such service sectors as banking, insurance, distribution, trading rights, tourism, telecommunications, transportation, accounting, auditing and legal services. Also, there are a number of laws protecting the interests of foreign investors as well.

\section{Pakistan \& China FTAs with other Countries:}

Both Pakistan and China are fully aware of the pitfalls of regionalization as well as isolation. Thus, keeping in mind the current global scenario they have signed various FTAs mostly with other emerging economies and nearby states.

\section{Chinese FTA with ASEAN}

The conceptualization of the Chinese FTA with ASEAN, known as CAFTA can be traced back to as early as 1995 when Thailand for the first time proposed a special economic zone, similar to an FTA with China's southern provinces. Later, the Asian Financial Crisis in 1997 and the U.S-led NATO bombing of China's embassy in Belgrade in 1999 led to discussions of the formation of an FTA from academic circles to the high policy-making level. Decision making by Chinese leadership to strengthen cooperation with ASEAN finally led to the Chinese tentative proposal of setting up an FTA with ASEAN in Singapore in 2000, and later a formal proposal in Brunei in 2001. It was on December 2, 2004 that China signed a free trade agreement with ASEAN. Being the first ever signed FTA by China, it caught the world's attention. The Chinese academia proposed a move beyond traditional modes of trade and tariff reduction to include cooperation in services (including financial, science and technology, including IT) electricity, agriculture, tourism and transportation (including air transport), non-traditional security and cross border crime (such as drug trafficking) and regional cooperation (such as GMS 
cooperation and building China's Southwest International Corridor through Yunnan).

In the view of some Chinese strategists, an FTA with Japan and Korea first would have better served the Chinese side because stronger economic complementarities would make them better partners than ASEAN. Fewer opportunities for domestic industries and more pressure will exist as a result of cooperation with ASEAN countries. Moreover, making further concessions to ASEAN as through CAFTA would increase the huge trade deficit with ASEAN which stood at $\$ 1.3$ billion in $1993, \$ 1.64$ billion in 1998, $\$ 2.7$ billion in 1999 and $\$ 4.8$ billion in 2000. However, despite these realities China did not have the confidence to open its market to economies that are bigger and far more advanced than its own. If China would have engaged in an FTA arrangement with Japan and Korea, thus reducing its current average tariff of $14 \%$ to the levels of Korea and Japan with the given huge bilateral trade volumes, the fear was that the final outcome would have been damaging. Moreover, the rise in the trade deficit because of Chinese agricultural products not finding better access into Japanese and Korean markets would not have been fairly compensated. Since by 2015 , China will be able to achieve full trade and investment liberalization it was better for it to choose ASEAN as a partner for an FTA. In addition to traditional areas of trade and investment, China's FTA with ASEAN is more than just an economic deal to cover political and security issues as well. Using this new regionalism as a precautionary measure to dilute potential U.S unilateralism in the region shows that CAFTA was both strategically as well as economically motivated.

According to analyst John Bishop (June 1, 2005) the CAFTA which was to be concluded by the end of June 2005 and implemented in 2010 will have significant implications for both China and ASEAN nations. China will benefit from improved trading access to the ASEAN customer base of 410 million people and increased imports of much needed raw material and food. But this will lead to the export of low value agricultural products to China from ASEAN while ASEAN will absorb higher value manufactured products from China leading to higher trade deficits for ASEAN nations.

\section{Chinese FTA with Chile}

The China- Chile FTA was signed on November 18, 2005 in Pusan. Since January 2005, five rounds of negotiations on market access, rules of origin, technical barriers to trade, SPS remedy, dispute settlement mechanism, and related legal and technical issues have already taken place. 
The China-Chile FTA will further deepen the partnership and the trade liberalization process will help unleash the potential of bilateral economic and trade cooperation and intends to set a new example in SouthSouth cooperation. According to the Ministry of Commerce China, after going through the respective internal approval procedures, the China-Chile FTA will start comprehensive tariff concessions in the latter half of 2006. On the Chilean side, the import tariff rate of $74 \%$ of the tariff lines will be lowered to zero immediately after the Agreement takes effect, while on the Chinese side, $63 \%$ of the import tariff lines will have zero rate within 2 years; the remaining import tariff lines of both parties will be zero rated in 5 to 10 years after the Agreement becomes effective. Each party may keep only $3 \%$ of the tariff lines as exceptions with tariff rates unchanged. This means that in 10 years after the start of the tariff concession process, the import tariffs on $97 \%$ of the tariff lines of both sides will be zero. Furthermore, the Agreement provides that the two parties may accelerate the tariff concession upon consensus through consultation. In addition to the liberalization of trade in goods, the Agreement also states the two sides will strengthen cooperation in such areas as economic matters, small and medium sized enterprises, culture, education, science and technology, environmental protection, labor and social security, IPR protection, investment promotion, mining and industry ${ }^{1}$.

The establishment of the China-Chile FTA has been seen as a milestone in the history of the China-Chile relationship, as Chile has always been an important trading partner of China in Latin America. The bilateral trade between the two countries has reached a level of US 5.4 billion during the period 2002-04, with a $22 \%$ annual average growth rate of Chinese exports to Chile and $42 \%$ of imports. Chile's imports from China comprise such products as light industrial products, electromechanical products and plastic products and Chile's exports to China are composed of such products as copper, fish powder, fruit and wine. The two economies have been strongly complementary to each other in industrial structure and import and export commodity mix. ${ }^{2}$

\section{Pakistan - SAFTA}

The Agreement on the South Asian Free Trade Area is an agreement reached at the 12th South Asian Association for Regional Cooperation (SAARC) summit at Islamabad, Pakistan on January 6, 2004. It created a

\footnotetext{
1 The Economic and Commercial Counselor's office of the Embassy of People's Republic of China, Nov. 18, 2005.

${ }^{2}$ ibid

${ }^{3}$ Wikipedia
} 
framework for the creation of a free trade zone covering 1.4 billion people in India, Pakistan, Nepal, Sri Lanka, Bangladesh, Bhutan and the Maldives. The seven foreign ministers of the region signed a framework agreement on SAFTA with zero customs duty on the trade of practically all products in the region by the end of 2012. The SAARC Preferential Trading Arrangement (SAPTA), with concessional duties on sub-continent trade, went into force on January 1, 1996. The new agreement i.e. SAFTA, came into being on January 1, 2006 and will be operational following the ratification of the agreement by the seven governments. SAFTA requires the developing countries in South Asia, that is, India, Pakistan and Sri Lanka, to bring their duties down to $20 \%$ in the first phase of the two year period ending in 2007. In the final five year phase ending 2012, the $20 \%$ duty will be reduced to zero in a series of annual cuts. The least developed country group in South Asia consisting of Nepal, Bhutan, Bangladesh and Maldives, gets an additional three years to reach zero duty.

\section{Pakistan - Sri Lanka FTA (PSLFTA):}

The Pakistan - Sri Lanka FTA was signed on July, 2002 and came into effect in June 2005. Immediately after the FTA became operational, Pakistan offered 206 items duty-free while Sri Lanka offered 106 items duty free, hence giving a special and differential treatment to Sri Lanka. Sri Lanka has been given a five year time period to phase out tariffs as compared to three years given to Pakistan. The Sri Lankan negative list consists of 697 items as compared to 540 items in Pakistan's negative list.

Items in the zero duty list of Pakistan (subject to application of the mutually agreed rules of origin) include frozen fish, vegetables, spices, fruits/juices, polymers of vinyl chloride in primary forms, natural rubber (excluding latex), raw silk, tanned/crust skins, wool, some varieties of paper and board, carpet and floor covering, non-alloy aluminum, iron and stee1 products and toys/dolls.

Sri Lanka's no-duty items under the FTA include chickpeas, dates, oranges, benzene, toluene, apparel and clothing accessories, ballbearing, penicillin/streptomycin/tetracycline and their derivatives and vacuum flasks (excluding glass inners).

Export markets for certain products are crucial for both Sri Lanka and Pakistan despite the fact that Pakistan and Sri Lanka have not been major trading partners over the years. For example, in order to benefit from duty free access of tea, Sri Lanka needs to create a strong marketing 
campaign to change the preference of the Pakistani consumers to bulk tea from CTS tea of which Kenya is a major producer.

Currently, trade between India and Pakistan takes place mostly via Singapore or Dubai. If Sri Lanka can promote Indo-Pakistan trade by encouraging Pakistani investors to open operations in Sri Lanka in order to trade with India using the ISLBFTA and vice versa, then Sri Lanka can gradually acquire hub status in South Asia. ${ }^{4}$

\section{Analysis and implications of Pakistan-China FTA}

The military and strategic relationship between China and Pakistan has always been strong. However, economic relations between the two countries have, unfortunately, not been as robust (as illustrated in Section 2). Bilateral trade, mutual investment (direct/portfolio or both), joint ventures and aid/loans represent components of the economy which, although they have been previously coordinated upon by the two economies, the scope for cooperation in these fields remain untapped.

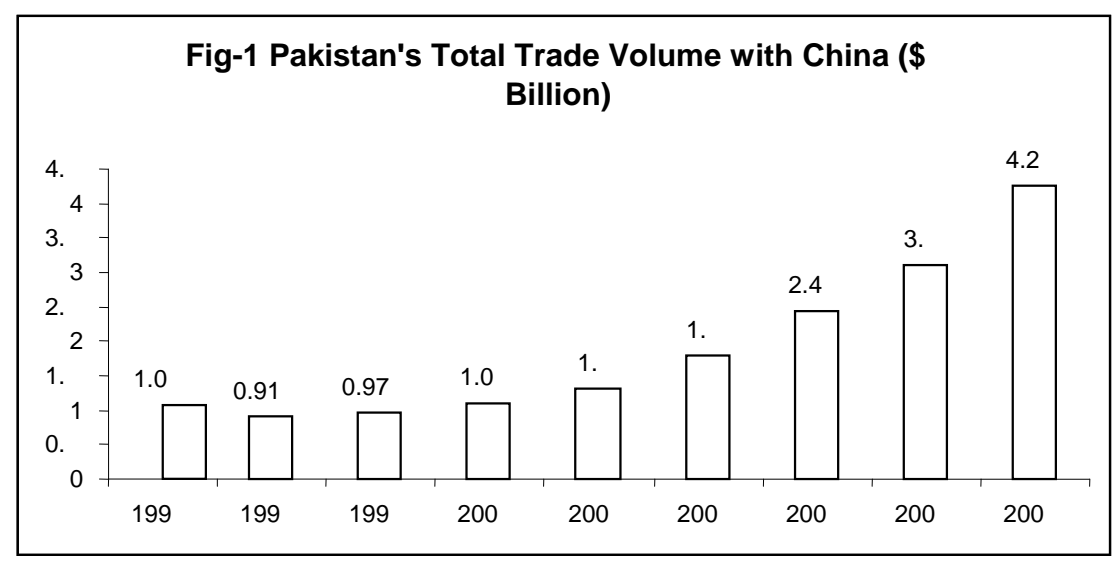

Source: IPCS Special Report 30, September 2006

China's trade has mostly been concentrated in markets of developed countries such as ASEAN, JAPAN and the US. However, its trade with East Asian and South East Asian neighbors has also been considerable in volume. China's exports to its six East Asian neighbors was $\$ 124.2$ billion and $\$$ 168.8 billion worth of goods in 2003 and 2004 as compared to the rest of Asia (minus Japan and the Middle East) where it exported goods worth \$28.6 billion and $\$ 40.4$ billion in the same time period. This includes many other

\footnotetext{
${ }^{4}$ Kalegama, S., “Sri Lanka's Free Trade Agreement with Pakistan”, Economic Watch.
} 
countries besides those of South Asia. So what share does Pakistan constitute and what is the importance of Pakistan as a market destination for China? As Table-1 shows, until 2000 China's share in Pakistan's external trade was less than $6 \%$ whereas it crossed the mark of $10 \%$ after 2003 . Moreover, before Chinese trade agreements came into force with India, Pakistan's share was only $20-25 \%$ on an average in terms of Chinese trade with South Asia, which has further declined at even the South Asia level.

Table-1: China's Total Trade Volume with Pakistan and Other Countries (\$ billion)

\begin{tabular}{lccccccccc}
\hline \multicolumn{1}{c}{ Year } & $\mathbf{1 9 9 7}$ & $\mathbf{1 9 9 8}$ & $\mathbf{1 9 9 9}$ & $\mathbf{2 0 0 0}$ & $\mathbf{2 0 0 1}$ & $\mathbf{2 0 0 2}$ & $\mathbf{2 0 0 3}$ & $\mathbf{2 0 0 4}$ & $\mathbf{2 0 0 5}$ \\
\hline Pakistan & 1.07 & 0.915 & 0.971 & 1.09 & 1.30 & 1.80 & 2.43 & 3.1 & 4.26 \\
& $(20.21)^{*}$ & $(18.74)$ & $(17.21)$ & $(18.88)$ & $(19.93)$ & $(19.47)$ & $(23.38)$ & $(27.90)$ & $(34.98)$ \\
India & 1.83 & 1.92 & 1.98 & 2.77 & 3.60 & 4.94 & 7.6 & 13.6 & 18.73 \\
SAARC & 3.9 & 3.89 & 4.15 & 5.35 & 6.43 & 8.31 & & & \\
ASEAN & 25.06 & 23.66 & 27.20 & 38.55 & 41.80 & 54.76 & 78.2 & 105.9 & 120 \\
Japan & 60.81 & 58.02 & 66.16 & 83.20 & 87.88 & 101.97 & 130 & 167.9 & 200 \\
USA & 49.03 & 54.99 & 61.49 & 83.30 & 80.61 & 97.31 & 126 & 169.4 & 211.63 \\
\hline
\end{tabular}

Source: IPCS, Special Report 30

* Figures in brackets refer to the total external trade volume of Pakistan in billion dollars.

Table-2 gives us China's exports to and imports from Pakistan over the span of the last fifteen years. This has been done to analyze the burgeoning trade deficit of Pakistan between the two trading partners. Over the years, bilateral trade with China has been on a very small scale. The share of Pakistan's exports to China in total exports was only in the range of $1-1.5 \%$ until the mid 90s. The table further shows that although the trade volume between the two countries has started to improve, it still remains in the range of $2-3 \%$ up to $2005-06$. On the other hand, imports from China have always been substantial over the period under consideration. During the decade of the 90s, imports from China have fluctuated between 4-5\%, and thereafter have steadily increased to $9.47 \%$ during 2005-06. The trade balance with China has always been negative for all time periods starting from the 1990s till 2005-06. However, it is important to note here that during the Korean War of the 60's, Pakistan's trade deficit actually registered a surplus with China. 
Table-2: China's Export to and Import from Pakistan (\$ million)

\begin{tabular}{ccccccc}
\hline Years & Exports & Imports & $\begin{array}{c}\text { Trade } \\
\text { balance }\end{array}$ & $\begin{array}{c}\text { Share of } \\
\text { Exports to } \\
\text { China in total } \\
\text { exports }\end{array}$ & $\begin{array}{c}\text { Share of } \\
\text { Imports from } \\
\text { China in total } \\
\text { Imports }\end{array}$ & $\begin{array}{c}\text { Share of trade } \\
\text { deficit with } \\
\text { China in total } \\
\text { trade deficit }\end{array}$ \\
\hline $1990-91$ & 60.83 & 386.12 & -325.29 & 0.99 & 5.07 & 21.86 \\
$1991-92$ & 55.47 & 399.77 & -344.31 & 0.80 & 4.32 & 14.66 \\
$1992-93$ & 41.60 & 420.96 & -379.36 & 0.61 & 4.23 & 12.13 \\
$1993-94$ & 53.67 & 439.00 & -385.33 & 0.79 & 5.13 & 21.88 \\
$1994-95$ & 90.63 & 458.03 & -367.40 & 1.11 & 4.41 & 16.28 \\
$1995-96$ & 145.82 & 546.17 & -400.35 & 1.67 & 4.63 & 12.92 \\
$1996-97$ & 103.38 & 542.91 & -439.53 & 1.24 & 4.56 & 12.30 \\
$1997-98$ & 160.99 & 510.37 & -349.39 & 1.87 & 5.04 & 23.45 \\
$1998-99$ & 159.71 & 416.47 & -256.76 & 2.05 & 4.42 & 15.53 \\
$1999-00$ & 180.35 & 471.62 & -291.26 & 2.10 & 4.57 & 16.74 \\
$2000-01$ & 304.14 & 525.14 & -221.00 & 3.31 & 4.89 & 14.47 \\
$2001-02$ & 229.06 & 574.94 & -345.88 & 2.51 & 5.56 & 28.70 \\
$2002-03$ & 244.57 & 838.42 & -593.85 & 2.19 & 6.86 & 56.02 \\
$2003-04$ & 288.11 & 1153.69 & -865.57 & 2.34 & 7.40 & 26.40 \\
$2004-05$ & 354.24 & 1842.91 & -1488.67 & 2.46 & 8.95 & 23.98 \\
$2005-06$ & 463.99 & 2706.32 & -2242.33 & 2.82 & 9.47 & 18.51 \\
\hline
\end{tabular}

Source: Pakistan Economic Survey, 2005-06

Amongst others, one of the reasons for the huge deficit between China and Pakistan can be attributed to the fact that Pakistan's exports have been highly concentrated in the markets of few a countries e.g., USA, Japan, Germany, Hong Kong, Dubai and Saudi Arabia. These countries alone account for almost $50 \%$ of Pakistan's total exports. In addition, Pakistan's exports are also excessively concentrated in a few items such as cotton, leather, rice, synthetic textiles, sporting goods, etc. Pakistan's exports to China mainly consist of cotton textile material, leather, chromium, mineral and crude oil, and aquatic products. The exports of these products have been very small as shown by the share of Pakistan's exports to China in total exports. 


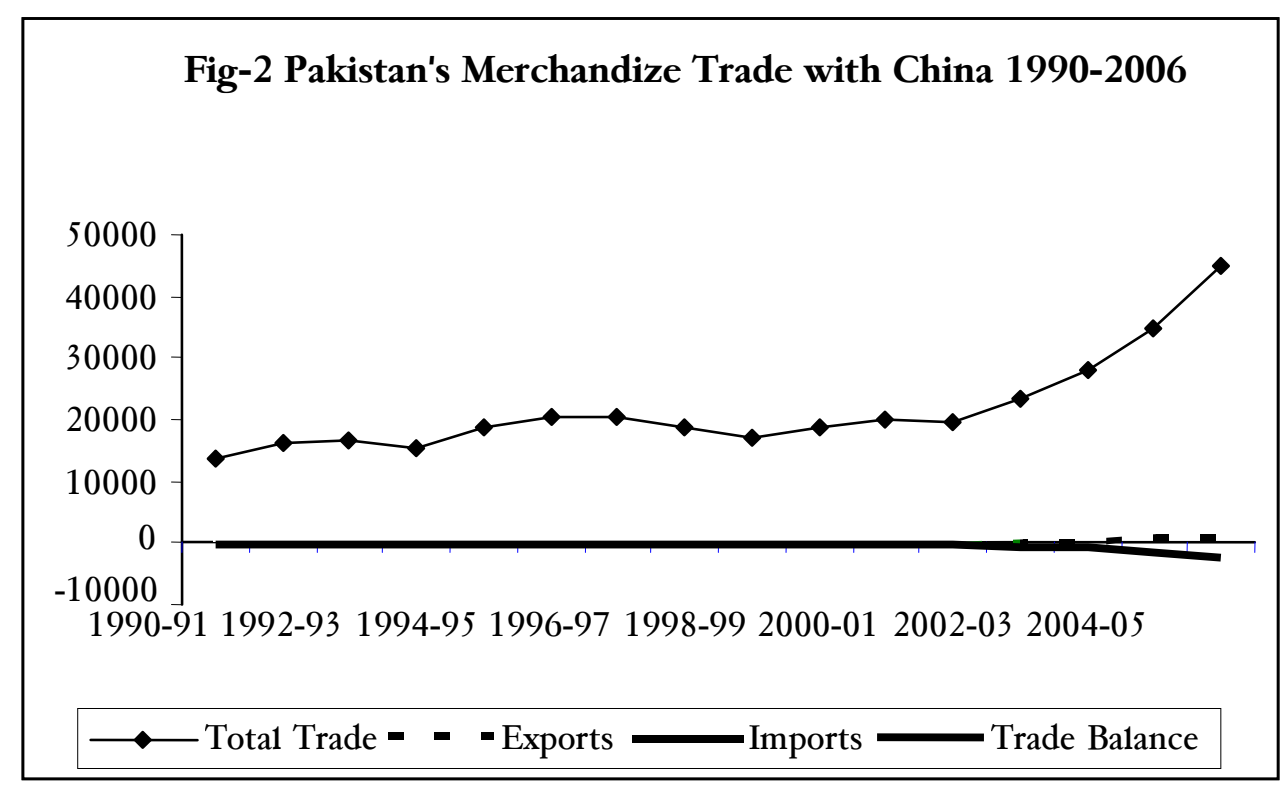

Source: Pakistan Economic Survey, 2005-06

On the import side, Pakistan's imports are mainly concentrated in the markets of a few countries, as $40 \%$ of imports continue to come from the USA, Japan, Saudi Arabia, Germany, U.K and Malaysia. Like exports, imports are also concentrated in a few products such as petroleum and petroleum products, machinery, chemicals, transport equipment, edible oil, iron and steel, fertilizers and tea. This concentration of imports has remained unchanged over the last one decade or so. Machinery, petroleum and petroleum products and chemicals alone account for almost $53 \%$ of these imports. Over the years, this composition of imports has not witnessed any remarkable change. Among consumer and capital goods, the share of raw material for consumer goods in total imports has been high while that for capital goods has declined. However, the share of capital goods has shown an increase, thereby representing an increase in investment in the country. The declining share of consumer goods, on the other hand, represents an increase in domestic production.

The share of the trade deficit with China in the total trade deficit shows that although Pakistan's exports to China have been very insignificant, the same is not true for imports from China. Pakistan mainly imports high tech products, chemicals, plastic products and house hold appliances, chemical materials, machinery, medicine, minerals, light industry products, native produce and animal byproduct from China. 
Under the recently signed Pakistan-China FTA, both countries have committed themselves to reducing or eliminating tariffs on all products in two phases starting from July 1, 2007. The first phase covers trade in goods and investment while the negotiations in the second phase i.e., trade in services will be held in mid 2007. An Early Harvest Programme (EHP) which has been operative since 1st January 2006 has been merged into this newly signed bilateral FTA. Under the EHP, China has brought to zero all tariffs on 767 items. For Pakistan, the overall package includes duty free access on industrial alcohol, cotton fabrics, bed-linen and other home textiles, marble and other tiles, leather articles, sports goods, mangoes, citrus fruit and other fruits and vegetables, iron and steel products and engineering goods. A $50 \%$ tariff reduction on fish, dairy sector products, frozen orange juice, plastic products, rubber products, leather products, knitwear, and woven garments will also be enjoyed by Pakistan under the FTA. China can get increased market access mainly on machinery, organic and inorganic chemicals, fruits and vegetables, medicaments and other raw materials for various industries including that of the engineering sector, intermediary goods for engineering sectors, etc.

During Phase I, within five years of the agreement coming into force, both parties will reduce tariffs on $85 \%$ of the products based on different extents of tariff reduction and at least $36 \%$ of the products will be tariff free within the first three years. China will mainly reduce tariff on livestock, aquatic products, vegetables, mineral products and textiles, whereas Pakistan will reduce tariffs generally on beef, mutton, chemicals and machinery products. Phase II will start in the sixth year of implementation of the agreement. Further reduction of the tariffs on various products will be based on the review of the implementation of the agreement. In terms of tariff lines and trade volumes, the intention of both countries is to eliminate tariffs on no less than $90 \%$ of the products, within a reasonable period of time.

In the preceding paragraphs we have already established the fact that Pakistan's exports to China are negligible as compared to its imports from there. This raises the concern that granting additional market access to China, through a reduction of tariffs under the FTA arrangement, might lead to harming Pakistan's economy rather than being beneficial e.g., Pakistan has agreed to reduce tariffs mainly on machinery, organic, and inorganic chemicals, fruits and vegetables, medicaments and other raw materials for various industries including that of the engineering sector, intermediary goods for engineering sectors, etc. Given the current export structure of Pakistan's economy, it becomes imperative to analyze the prospective impact of this FTA on Pakistan's economy. 
Presently Pakistani markets are heavily flooded with cheap Chinese smuggled goods - a major part of the illegal trade in the country. A legal channel for the trade of these commodities, even in the absence of an FTA, can make Pakistan's trade volume double with China. Since smuggling normally takes place to save on custom duties/tariffs, the implementation of the FTA makes such activities useless or non-profitable since tariffs/duties saved by the smugglers have largely been removed under the FTA. Legal documentation of these commodities will have a positive impact on Pakistan's economy. Although the goods being shipped from China to Pakistan and vice versa will be duty free, they will still be registered thus enabling the government to collect revenue in the form of income/sales tax on them. As we see an influx of cheap Chinese products enter Pakistan under the FTA, this can be good for Pakistan's economy in the sense that documentation leading to subsequent tax generation will increase CBR collection for the country.

Besides the aforementioned products, there are other specific products in which China is more competitive than Pakistan. The procurement of many of these products is vital for the Pakistani economy as well e.g., textile, cotton yarn and garments represent a major share of Pakistan's total exports. Opening the Chinese economy to these sectors would obviously mean a replacement of domestic production by cheap imports from China. Since Pakistan is in the initial stages of development, it is trying to expand its industrial base through the expansion in its production of semi-finished and finished products. Therefore, strengthening its engineering sector, auto sub-sector, consumer durables mainly domestic appliances needs at least at this point in time some protection in order for the booming trend in the economy to be sustained.

One of the most frequent and recurrent concerns regarding any FTA is that the impending FTA, allowing for an influx of various goods, might stifle the indigenous industry of the less developed country or the country having a smaller economy. In the case of Pakistan - China FTA similar reservations have been expressed by various strata of the society especially industrialists, small business operators as well as academia of the country. Pakistan being a smaller economy as compared to China is compelled to look out for its local industries. Since the removal of duty on almost $90 \%$ of tradable products between the two countries could have spelt disaster for the textiles, garments, and engineering industries, which although booming at present are still in their infancy and thus are in not a position to face a deluge of cheap Chinese goods. Realizing the dangers associated with the implementation of an FTA, both the countries have 
agreed to induct a separate clause in the agreement to abolish this concern once and for all. Article 25, a part of the newly signed agreement, related with both dumping and countervailing duties, states specifically that no dumping will be tolerated and thus steps to stop this practice have been finalized.

The following sectors of the economy have been provided protection by Pakistan under the FTA.

\section{Cotton Yarn, Textile and Garment Sectors}

Cotton yarn is subject to a tariff of $5 \%$ which will remain at $5 \%$ during the first phase of the Pak-China FTA. The duty on textiles and garments, which is $25 \%$, would be reduced to $20 \%$ in 5 years. The polyester sector, including fabrics and garments, have been put in the No Concession List and no duty reduction will take place in the first five years.

\section{Textile Sector}

The share of the textile industry in the economy along with its contribution to exports, employment, foreign exchange earnings, investment and value added makes it the single largest manufacturing sector of Pakistan. It contributes around $8.5 \%$ to GDP, employs $38 \%$ of the total manufacturing labor force, and contributes between $60-70 \%$ to total merchandise exports. Indeed, with exports reaching about $\$ 8.6$ billion in 2004-05, Pakistan is one of the largest textile exporters in the world. The variety of products ranging from cotton yarn to knitwear, garment made-ups and bedwear are the most important export products with an export value of about $\$ 1.35$ billion each. Knitwear, ready made garments and cotton yarn also have important shares in total exports. Overall, the US and the EU are Pakistan's largest trading partners accounting for 25\% and 20\% shares of Pakistani exports respectively. Other major importers include China, the UAE and Saudi Arabia. The textile trade is classified into two broad categories i.e. textiles which include yarn, fabric and made-ups, and clothing which represents ready-made garments.

${ }^{5}$ Economic Survey of Pakistan 2005-06, Manufacturing, Mining and Investment Policies (Ch: 3). 


\section{Fig-3 Composition of Pakistan}

Textile Exports 2004-05

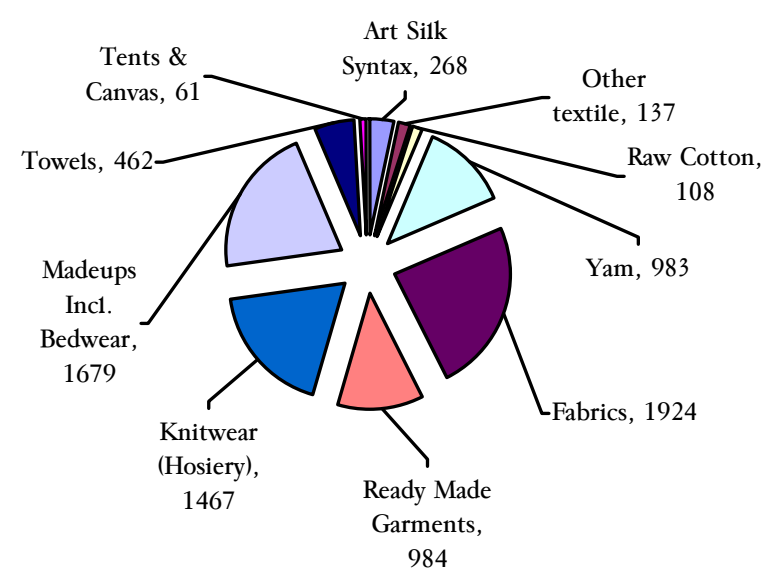

Source: Pakistan Economic Survey, 2005-06

\section{Ready Made Garments Sector}

Pakistan, with total exports of around US\$ 1 billion, has a meager share of $1 \%$ in the global apparel market. The apparel export product mix from Pakistan is heavily tilted towards men's wear and knitted garments.

The major thrust of garments and made-ups exports from Pakistan is towards the USA market. The European Union is the second largest market for garment manufacturers from Pakistan. The major markets that Pakistani manufactures have so far not been able to explore are the Japanese, Far East and Middle East markets. These markets demand high product standards and in return offer higher unit price realizations. The shift towards newer product and non-traditional markets can only be brought about by more emphasis on synthetic garments, and the development of a marketing and research infrastructure for the industry.

The production of garments and made-ups in Pakistan is concentrated mainly in Lahore, Faisalabad and Karachi. These three clusters have their own specialties. Faisalabad caters more to home textiles, Lahore is the home of knitwear and Karachi lives up to its reputation of being "mini Pakistan," having established itself both in the knit as well as the woven side of the industry. 


\section{Engineering Sector}

In the steel sector, the prime quality goals are subject to a $10 \%$ duty which will be reduced to $5 \%$ in 5 years and secondary goods subject to duty of $20 \%$ would be reduced to $16 \%$ in 5 years.

The engineering sector accounts for a $63 \%$ share in world trade. To achieve any significant share of the world trade in engineering goods and services, Pakistan will have to do many things which include improving universities, polytechnics and factories for the kind of manufacturing prowess and design capabilities required by the world market, which now stands spoilt for choices. In this context, an important step has been taken by the restructuring of the Engineering Development Board.

In Pakistan, large-scale manufacturing companies in the engineering sector lack export strategies as well as export development. While Japan, Korea and Malaysia rely on their large-scale companies to spearhead the export push, in Pakistan this is being conveniently left to the SME sector. The government needs to look at this deficiency and bring the strength of the large scale manufacturing sector into play for a quantum jump in the export of engineering goods and services.

\section{Auto Sub-Sector}

Vehicles in CBU, SKD and CKD condition and auto parts classified under any of the headings of Pakistan Customs Tariff have been protected and no duty reduction has been committed to for the first five years.

The auto industry is considered globally as the mother of all industries. The automobile industry has the largest segment in world trade. The annual size of automotive exports has grown over $\$ 600$ billion, which accounts for about $10 \%$ of world exports. In today's fast globalizing world, changing models, improving fuel efficiency, cutting costs and enhancing user comfort without compromising on quality are the most important challenges of the industry. The auto industry in Pakistan is growing fast and may soon begin to achieve economies of scale. This mechanical revolution has been aided in part by sound macro-economic policies pursued during the last seven years. Furthermore, the e-pass scheme for electronic goods, unchanged auto policy over the last few years, liberal adjustment of the tax regime to lower duties on raw materials and intermediate products have also helped in the rapid expansion of the auto sector. The tremendous rise in automobile demand has resulted in increased production, giving a healthy impetus to industrial output and generating over 150,000 direct 
employment opportunities besides contributing tax revenue to the national exchequer.

Since 2001-02, the automobile market has been growing rapidly by over $40 \%$ per annum and if an average annual growth of $30 \%$ per annum is maintained, Pakistan's market will cross the milestone of 500,000 units by the year 2010. Long-term investment friendly policies of the government and up-gradation of production facilities are considered as a pre-requisite by experts to achieve the automobile vision 2010 of 500,000 units.

\section{Consumer Durables- Domestic Appliances}

All domestic appliances have either been completely protected or the duty will be reduced from $25 \%$ to $20 \%$ and $20 \%$ to $16 \%$ in 5 years.

Riding high on rapidly growing demand, the home appliance industry in Pakistan is expected to double its capacity of producing TVs, refrigerators and deep freezers by 2009. Refrigerators lead the figure of the current year with 569,756 units. The production of TVs, refrigerators and deep freezers amounted to 372,192, 233,000 and 120,000 respectively in 2000-01. The production of these items has almost doubled in a short span of three years. If this trend continues, the home appliance industry would double its production and will increase its contribution to GDP, and accordingly contribute revenue to the national exchequer. An added benefit is the increase in direct jobs in the industry and the vendor industry.

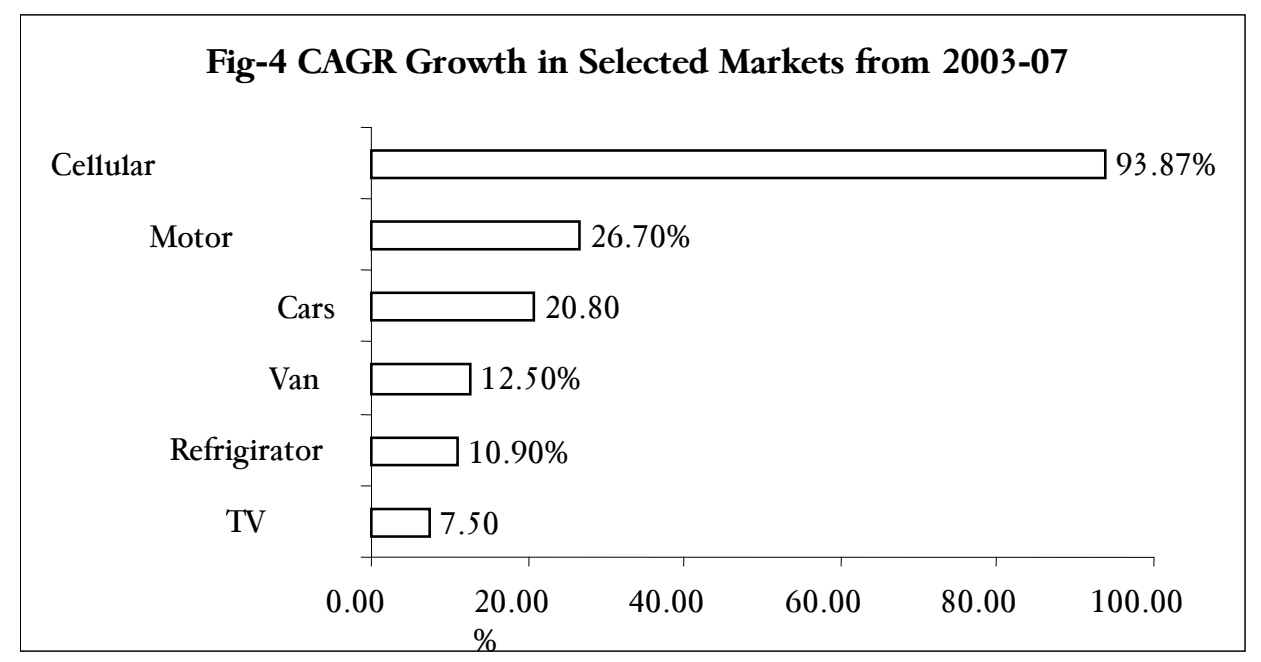

Source: PRSP II 
The pace of growth in demand for home appliances is the direct result of the banks and leasing companies' policy of consumer financing packages together with the relaxation through and e-pass schemes. Many dealers have initiated their own schemes of easy installments thus further escalating demand.

The following sectors have also been protected by Pakistan in the contract:

- Food basket

- Cigarettes

- Locally manufactured inorganic and organic chemicals

- Plastic products

- Edible products e.g., Edible oils

- Paper and paper board

- Engineering goods

In order to boost trade ties between China and Pakistan, duties/tariffs on items of mutual interest have been reduced drastically. In some cases it has been decided that the duties be completely written off over a period of 5 years. The table given below shows the three stages of tariff reduction to be implemented under the FTA for both Pakistan and China.

In the case of exports, as we have shown in Table-2, Pakistan's exports to China are a very small proportion of the country's total exports. If Pakistan can increase its exports to China through increased market access for commodities which were earlier under the high tariff lines, then it will be highly beneficial for Pakistan's economy. As shown in Table-3 certain export items e.g., leather articles, cotton fabrics, bed linen and home textiles, marble and other tiles, sports goods, citrus fruits (kinoo, lemon, lime) and other citrus fruits will be rendered tariff free in three stages. However, we are well aware of the fact that the composition of Pakistan's exports to China are primary in nature as they consist of cotton, textile material, leather, chromium, mineral and crude oil, and aquatic products etc. 
Table-3: Tariff Structure

\begin{tabular}{|c|c|c|c|c|}
\hline \multirow[t]{2}{*}{ Products } & \multirow{2}{*}{$\begin{array}{l}\text { MFN Tariff } \\
\text { of China }\end{array}$} & \multicolumn{3}{|c|}{ Tariff for Pakistan } \\
\hline & & On $1 / 1 / 2006$ & On $1 / 1 / 2007$ & On $1 / 1 / 2008$ \\
\hline Cotton fabrics & $10-14$ & 5 & 0 & - \\
\hline $\begin{array}{l}\text { Bed-linen \& home } \\
\text { textiles }\end{array}$ & 14 & 5 & 0 & - \\
\hline Synthetic yarn & 10 & 5 & 0 & 0 \\
\hline Polyester fabrics & $10-15$ & 5 & 0 & 0 \\
\hline Polyester yarn & 5 & 0 & 0 & 0 \\
\hline $\begin{array}{l}\text { Indentured industrial } \\
\text { alcohol }\end{array}$ & 4 & 10 & 5 & 0 \\
\hline $\begin{array}{l}\text { Dentured industrial } \\
\text { alcohol }\end{array}$ & 30 & 10 & 5 & 0 \\
\hline Leather articles & 10 & 5 & 0 & - \\
\hline Marble \& other tiles & 24 & 10 & 5 & 0 \\
\hline Table ware & 18 & 10 & 5 & 0 \\
\hline Sports goods & 14 & 5 & 0 & 0 \\
\hline Mangoes & 15 & 5 & 0 & 0 \\
\hline $\begin{array}{l}\text { Citrus fruits (kinoo, } \\
\text { lemon, lime etc.) }\end{array}$ & 12 & 5 & 0 & 0 \\
\hline Other citrus fruits & 30 & 10 & 5 & 0 \\
\hline
\end{tabular}

Source: Ministry of Commerce, Government of Pakistan

Furthermore, increased exports of these products because of enhanced market freedom can lead to increased revenue generation but will not necessarily diversify Pakistan's exports and will also not strengthen the industrial base of the country. However, all is not lost; it must be remembered that since Pakistan's exports are highly concentrated in cotton, leather, rice, synthetic textile and sport goods - a one billion consumer market of China will be advantageous for Pakistan and can diversify Pakistan's exports in terms of destination.

China being an emerging economy is trying to raise the living standard of its rural populace. Thus, it offers huge potential for Pakistani exporters, especially in areas of agricultural, aquatic and leather products. According to the Chinese Feasibility Study on FTA, "The Pakistani 
commodities that have the greatest potential to be exported to China are tropical fruits. These fruits are widely planted in Pakistan, and China has already finished quarantine and inspection on Pakistani mangoes and citrus. After zero tariffs are levied, in North-west China, Pakistani fruits will enjoy certain advantages in both quality and price compared with the fruits grown in Southern China. Pakistan is also rich in fishery resources. With the adjustment of polices on fishery industry and the improvement of technology, the potential of Pakistan's fishery industry will be unleashed. After the zero tariff policy is adopted, Pakistan will see a rise in its exports to China."

These opportunities show that Pakistan can divert its exports from the markets of various other countries that have put high tariffs barriers on Pakistani imports and allow them to flow towards the Chinese borders under the guise of the newly formulated FTA. These advancements under the FTA will not only increase the trade volume with China but will also guarantee exposure to Pakistani products in the world's second largest economy, thereby making Pakistan a force to be reckoned with in the region.

In addition to market access, the FTA also covers clauses related to investments, including its promotion and protection, its treatment, expropriation, compensation for damages and losses and dispute settlement. The historic ties of investment between China and Pakistan have already been covered in detail in Section 2 of the paper.

Bilateral trade between China and Pakistan in recent years has made considerable progress, - increasing with an annual average rate of $30 \%$ in the past 5 years and exceeding $\$ 4.2$ billion in 2005 . In the first 9 months of 2006, Sino-Pakistan trade amounted to $\$ 3.75$ billion, thus, making China the third biggest trading partner of Pakistan.

Over the course of the last six decades, China and Pakistan have witnessed a steady growth in mutual investments, however the scale of investment is still relatively small. According to statistics released by the Board of Investment, out of a total FDI of \$1524 million that was invested in Pakistan during 2004-05, the Chinese share was only $\$ 443,763$. Chinese investment in Pakistan at the moment is concentrated mainly in Gwader port construction, exploration of coal and other resources, nuclear power stations, hydroelectric power stations, ship-building, machinery, infrastructure, construction, agriculture and manufacturing. 
Table- 4: Mutual Investment between China and Pakistan

\begin{tabular}{lccc}
\hline \multicolumn{3}{c}{ Pakistan's Investment in China } & $(10,000$ \$) \\
\hline & $\mathbf{2 0 0 3}$ & $\mathbf{2 0 0 4}$ & By 2004 \\
\hline Number of Projects & 19 & 21 & 96 \\
Contractual Value & 1949 & 3210 & 7148 \\
Actual Investment & 343 & 454 & 1700 \\
China's Investment in Pakistan & $(10,000 \$)$ & & \\
Number of Projects & 4 & 3 & 34 \\
Contractual Value & 930 & 7344 & 10411 \\
\hline
\end{tabular}

Source: Chinese Feasibility Study on Free Trade Agreement (March 15, 2005)

Chinese private as well as public sector corporations are launching big budget projects, especially in the manufacturing and construction sectors, all over the country. Some of the major Chinese companies operating in Pakistan are Heirs, ZTE, Howai Technologies, China National Petroleum Corporation, China State Construction Engineering Corporation, Dong Fang Electric Corporation, CMEs, China Ocean Shipping Corporation and Air China. The successful implementation by various Chinese joint ventures will encourage more Chinese as well as other foreign investment to step into Pakistan.

The signing of the FTA is projected to be beneficial for both the countries. If Pakistan is going to benefit from increased investment flows to the country, Pakistan is an important market for China to engage in the project contracting business in South Asia. In recent years, the average value of signed contracts of 1abor services amounted to about US\$ 500 million per year. By the end of Sept. 2006, the total value of contracted engineering and labor service cooperation projects of China in Pakistan amounted to US\$ 8.64 billion and the turnover was US\$ 7.2 billion. By September 2006, the agreed investment of China in Pakistan was US\$ 110 million and the actual investment of Pakistan in China was more than US\$20 million. 
Fig-5 Sector-wise Chinese Investment 2004-05 (\$)

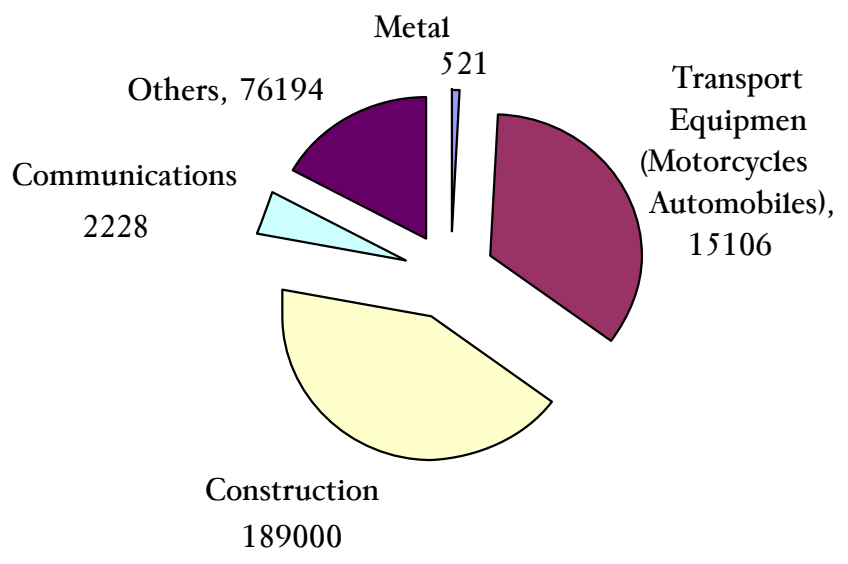

\section{Source: Pakistan Board of Investment}

As shown above, Chinese investment in Pakistan is substantial, covering IT and telecom, oil and gas, power generation, engineering, automobiles, infrastructure and mining sectors. Yet Pakistan's investment in China is not on the same scale. During 2004, Chinese firms were involved in investment in Pakistan for a contractual value of approximately $\$ 10,411$ compared to Pakistani investment of only $\$ 1700$ million. Signing of an FTA provides safeguards for the promotion of investment between the two countries but given the existing investment volume and investment friendly opportunities offered by the Government of Pakistan, China will be in a better position to utilize the benefits being offered, in lieu of yields including profits/dividend/capital gains as compared to Pakistani firms operating in China.. However, they can positively contribute to the development of Pakistan by generating new employment opportunities, transfer of technology, exposure to new products and markets; but it should be kept in mind that the primary aim of any multinational is to maximize profits and there are pros and cons associated with allowance of these investments to enter an economy.

\section{Conclusion}

Pakistan's FTA with China is another strategic link in the chain which Pakistan initiated in order to negotiate bilateral and regional preferentia1/free trade agreements. Pakistan aims to seek enhanced market access, by addressing tariff/non-tariff barriers, facilitating and further 
promoting trade, improving investment and economic development, augmenting comparative value of its exports and build added capacity in specified targeted areas through technical cooperation and collaboration through entering into such an arrangement.

The present paper undertakes a general analysis of the implications of the Pak-China FTA. The inferences drawn from the present analysis is that although Pakistan's economy is much smaller than that of China's in terms of GDP, trade, reserves etc., yet the FTA offers a huge potential for Pakistan's economy. Pakistan can change the trend of its chronic trade deficit with China by utilizing the increased market access given by China. Pakistan can also reduce its overall trade deficit by diverting its exports from traditional destinations to the new one billion consumer base of China; but for that Pakistan has to make its exports more competitive, more diversified and much better in quality. Increased investment flows will enhance the capacity of the existing industries, will help in technology transfer, and generate employment opportunities for the local population, thereby positively contributing to the economy of Pakistan. However, the Pakistani side would be less able to enjoy the concessions given by China for investment opportunities because the volume of investment to China from Pakistan is negligible. Nonetheless, we should not look at the FTA from this perspective, that if there are only positive implications for Pakistan, then why has China entered into such a deal? We know from the facts and figures that economy-wise China is already far along the road to development, and for big and developed economies, political and security matters much more than economic considerations in making such decisions of mutual cooperation. Pakistan's strategic geographical location makes it a valuable ally which can act as a trade corridor for countries such as China. 


\section{References}

Ceylon Chamber of Commerce, "Sri Lanka - Pakistan Free Trade Agreement”.

China Study Center, Institute of Strategic Studies. “Area Brief on China (2007)",

China Daily, “ASEAN-China FTA Benefits Both Sides”, April 32002.

Chinese Feasibility Study on Free Trade Agreement, Online Search, March 15,2005 .

Economic and Commercial Counsellor's Office of the Embassy of the People's Republic of China in the Republic of Croatia., "China and Chile Signed FTA Agreement”, November 182005.

Government of Pakistan. "Five Year Development Program on Trade and Economic Cooperation between Pakistan and China”, Economic Affairs Division.

Government of Pakistan, "Pakistan - China Free Trade Agreement", Economic Affairs Division.

Government of Pakistan, Economic Affairs Division. Poverty Reduction Strategy Paper (PRSP) II 2007.

Hong, H., 2004, “ASEAN and China Sign “Dirty” FTA”, Taipei Times, Dec. 18.

IPCS, Special Report 30, September 2006.

Kalegama, S., "Sri Lanka's Free Trade Agreement with Pakistan”, Economic Watch.

Kumar, A., 2006, "China-Pakistan Economic Relations", Institute of Peace and Conflict Studies, special report 30 .

Lijun, S., 2003, "China-ASEAN Free Trade Area: Origins, Development and Strategic Motivations”, ISEAS Working Paper, International Politics \& Security Issues Series No. 1. 
Nag, B., 2005, “Trade Cooperation and Performance in East and South Asia: Towards a Future Integration”, South Pacific Development Journal, Vol. 12, No. 1, pp. 1-29.

Pakistan Economic Survey, various editions.

People's Daily Online, “China Established Nine FTAs in Past Five Years”, February 92006.

People’s Daily Online, "Sino-Pakistan Trade on Upward Trend”, August 13 2000.

Philippine Daily Inquirer, "China-ASEAN FTA to Boost Regional Integration”, June 12005.

Website of General Administration of Customs China.

Website of Pakistan Board of Investment. 